\title{
SUB-ACUTE TOXICITY EVALUATION OF ETHANOL EXTRACT OF RHEUMATIC TEA FORMULA (A POLYHERBAL TEA) IN WISTAR RATS
}

\author{
*Aliyu, M. and Samaila, S.C. \\ Department of Pharmacology and Therapeutics, Faculty of Pharmaceutical Sciences, Bayero University, Kano, \\ Nigeria \\ *Correspondence author: maliyu3288@gmail.com
}

\section{ABSTRACT}

Sub-acute toxicity profile of Rheumatic Tea Formula (RTF), a polyherbal tea consisting of Salix alba, Eucalyptus globulus and Albizia chevalieri was investigated in wistar rats of both sexes. Wistar rats were orally administered three different doses of ethanol extract of RTF for 28 days after which the effect on body weight, feed consumption, water intake, liver and kidney functions as well as haematological parameters were evaluated. Also evaluated was the histolopathogical effect of the extract on the liver, kidney, spleen and stomach. The extract significantly $(p<0.05)$ reduced body weight, feed consumption and water intake in rats. On liver function, there was no significant effect of Alanine Aminotransferase (ALT) and Aspartate Aminotransferase (AST); however there was significant $(p<0.05)$ elevation of Alkaline Phosphatase (ALP). No significant effect $(p>0.05)$ on kidney function indices was observed. There was also no significant effect $(p>$ $0.05)$ on haematological parameters, except for WBC differentials where there was significant $(p<$ $0.05)$ elevation of lymphocytes and decrease in neutrophils. The extract was relatively non-toxic on kidney, liver, spleen, and stomach in the histopathological evaluations. The present study suggests that RTF extract might have no serious deleterious effect on sub-acute administration.

Keywords: Rheumatic Tea Formula, sub-acute toxicity, liver, kidney, blood, wistar rats.

\section{INTRODUCTION}

Plants and herbs have been used since ancient times to cure various ailments. By the middle of the nineteenth century, approximately $80 \%$ of all medicines were derived from herbs (Arsad, et al., 2013). Herbal medicine is recognized as the most common form of alternative medicine (Ogbonnia et al., 2011). The use of herbal medicine in the treatment of disease conditions has been expanding rapidly and globally. Herbal prescriptions and natural remedies are commonly employed in developing countries for the treatment of various diseases. This practice is an alternative way to compensate for some perceived deficiencies in orthodox pharmacotherapy (Sofowora, 1989). This is attributed to affordability, accessibility and efficacy of herbal remedies (Eldin and Dunford, 1999). To date, herbs have remained useful not only as remedy for different diseases that affect humans and animals, but also as good starting points for the discovery of bioactive molecules for drug development (Ifeoma and Oluwakanyinsola, 2013). This popularity and availability of the traditional remedies have generated concern regarding the safety, efficacy and responsibilities of practitioners using traditional remedies (Chan, 1995).This necessitates the need for pre-clinical toxicity studies on herbal remedies. Toxicity testing can reveal some of the risk that may be associated with use of herbs, therefore avoiding potential harmful effects when used as medicine (Ifeoma and Oluwakanyinsola, 2013).
Rheumatic Tea Formula (RTF) is being employed as polyherbal remedy in the treatment of pain and inflammation associated with rheumatism, in Gwarzo Local Government Area of Kano state, Nigeria, by members of National Association of Nigerian Traditional Medicine Practioners (NANTMP). The remedy is being dispensed as tea bags and taken for a long duration (about 3-4 weeks) and hence exposes patients to possible harm. The ethanol extract of the polyherbal remedy consisting of three plants (Salix alba, Eucalyptus globulus and Albizia chevalieri ) may possess additive or synergistic toxicity as against the individual herbs when used alone. This calls for this study to investigate the sub-acute toxicity of the polyherbal remedy in rats.

\section{MATERIALS AND METHODS}

Collection of sample

Rheumatic Tea Formula (RTF) was collected from the National Association of Traditional Medical Practitioners in Gwarzo LGA of Kano State, Nigeria. The tea bags were then emptied and the powdered content collected.

Preparation of the extract: Four hundred and sixty four grams (464 g) of RTF was extracted with seventy percent aqueous ethanol $(70 / 30 \mathrm{v} / \mathrm{v})$ by cold maceration for 7 days to ensure maximum extraction with occasional stirring. The extract was filtered to remove the mac and the filtrate evaporated to dryness over a water bath at 50 degree Celsius $\left(50^{\circ} \mathrm{C}\right)$. The extract was stored and prepared freshly when required for experiment. 
Animals: Adult Wistar rats of both sexes weighing between $110-250 \mathrm{~g}$ were used during this work. The rats were obtained from animal house of Ahmadu Bello University Zaria, Nigeria. The animals were kept at the animal house of the Department of Pharmacology, Bayero University Kano. They were kept under normal conditions with free access to food and water. The animals were allowed at least twenty four hours (24 hrs) to acclimatize before commencement of the study.

Sub-acute toxicity studies: Twenty four (24) rats were divided into 4 groups of six rats each, group 1 (control) was treated with normal saline, groups 2-4 were treated with $125,250,500 \mathrm{mg} / \mathrm{kg}$ body weight of RTF extract, respectively. The extract was administered orally daily for 28 days $(p . o)$. During the course of the study, feed consumption and water intake were recorded on daily basis, while the body weight was recorded after every 7 days. At the end of the 28 days experiment, the animals were anaesthetized using formalin and then sacrificed. Blood was collected through the jugular vein in EDTA bottles for haematological studies and plain sterile bottles for serological studies. The kidneys, liver, spleen and the stomach were also removed and kept in a container filled with formalin for histological studies. The serum was analysed for Alanine Aminotransferase (ALT), Aspartate Aminotransferase (AST), Alkaline Phosphatase (ALP) and bilurubin (King and Armstrong, 1954). Haematological indices evaluated were; haemoglobin $(\mathrm{Hb})$, packed cell volume (PCV), red blood cell (RBC) count, white blood cell (WBC) count and differential WBC count using the method of Tietz (1985).

Tissue histology: Kidney, liver, spleen and stomach were harvested and kept fixed in 10\% formalin for seven days, organs were then embedded in paraffin wax. The organs were sectioned with thickness of $5 \mu \mathrm{m}$ and were then stained with haematoxylin and eosin. Each section was observed under light microscope at high power magnification for changes and photomicrographs were captured.

Statistical Analysis: All data were expressed as mean \pm standard error of the mean (SEM). Statistical differences were determined using student's t-test, with significance in difference when $p<0.05$.

RESULTS

Sub-Acute Toxicological Assessment

Body Weight: The ethanol extract of RTF significantly $(p<0.05)$ decreased weight of rats at
$125 \mathrm{mg} / \mathrm{kg}$ dose in the first three weeks of the experiment, while $250 \mathrm{mg} / \mathrm{kg}$ dose was significantly ( $p$ $<0.05$ ) observed to reduce weight at second and third weeks of administration. The highest dose $(500 \mathrm{mg} / \mathrm{kg})$ significantly $(p<0.05)$ reduced weight of rats in all the four weeks of the experiment compared with the control (Table 1).

Feed consumption: Significant $(p<0.05)$ reduction in feed consumption was observed at doses of 125 and $250 \mathrm{mg} / \mathrm{kg}$ in the first three weeks of the experiment while dose of $500 \mathrm{mg} / \mathrm{kg}$ showed significant $(p<0.05)$ reduction during the four weeks of the experiment (Table 2).

Water intake: The extract at highest dose of 500 $\mathrm{mg} / \mathrm{kg}$ showed significant $(p<0.05)$ reduction in water intake throughout the four weeks of the experiment, while significant $(p<0.05)$ reduction in water intake at the remaining doses were observed in the second and third weeks of the experiment (Table 3).

Biochemical parameters: ALT and AST parameters were not significantly affected by the extract. There was significant $(p<0.05)$ elevation of ALP at doses 250 and $500 \mathrm{mg} / \mathrm{kg}$. The extract at all doses showed no significant difference in both free and total bilirubin compared with the control (Table 4).There was significant $(p<0.05)$ reduction in level of creatinine at doses of 125 and $250 \mathrm{mg} / \mathrm{kg}$, however there was no significant change in the level of blood urea at all administered doses (Table 5).

Haematological parameters: There was a significant $(p<0.05)$ increase in total protein at doses of 250 and $500 \mathrm{mg} / \mathrm{kg}$ compared to the control while the other blood parameters were insignificantly affected (Table 6 ). Lymphocytes were significantly ( $p$ $<0.05$ ) elevated at all doses tested. The extract also caused significant $(p<0.05)$ decrease in neutrophils and monocytes (Table 7).

Tissue histology: The extract at 125 and $500 \mathrm{mg} / \mathrm{kg}$ doses showed slight hepatocellular necrosis while at $250 \mathrm{mg} /$ dose the liver showed slight hepatocellular necrosis with kupfer cells hyperplasia. The extract showed intense lymphocyte hyperplasia with necrosis of red pulp and pigments in the spleen. The kidney showed various degrees of necrosis of tubules and glomerulus with vacoulation and lymphocytes hyperplasia. The extract showed normal stomach epithelium in all doses except at dose of $250 \mathrm{mg} / \mathrm{kg}$ where moderate necrosis of the stomach epithelium devoid of ulceration was observed (Table 8).

Table.1 Effect of RTF ethanol extract on weight of rats

\begin{tabular}{lllll}
\hline Treatment $(\mathrm{mg} / \mathrm{kg})$ & & Change in wt $(\mathrm{g})$ & \\
& Week 1 & Week 2 & Week 3 & Week 4 \\
Control 1ml & $20.5 \pm 2.2$ & $28.3 \pm 4.9$ & $34.0 \pm 5.5$ & $38.0 \pm 10.3$ \\
RTF 125 & $1.2 \pm 4.3^{\mathrm{b}}$ & $-3.8 \pm 3.8^{\mathrm{c}}$ & $12.5 \pm 5.0^{\mathrm{a}}$ & $12.7 \pm 9.6$ \\
RTF 250 & $19.8 \pm 2.1$ & $0.3 \pm 2.3^{\mathrm{c}}$ & $20.2 \pm 5.0^{\mathrm{a}}$ & $18.5 \pm 5.3$ \\
RTF 500 & $0.0 \pm 6.7^{\mathrm{a}}$ & $6.0 \pm 3.9^{\mathrm{b}}$ & $7.3 \pm 3.9^{\mathrm{b}}$ & $6.5 \pm 6.7^{\mathrm{a}}$ \\
\hline
\end{tabular}

$\mathrm{a}=p<0.05, \mathrm{~b}=p<0.005, \mathrm{c}=p<0.001 . \mathrm{n}=6$, (t-test)

RTF $=$ Rheumatic Tea Formula 
Table.2; Effect of ethanol extract of RTF on feed consumption in rats

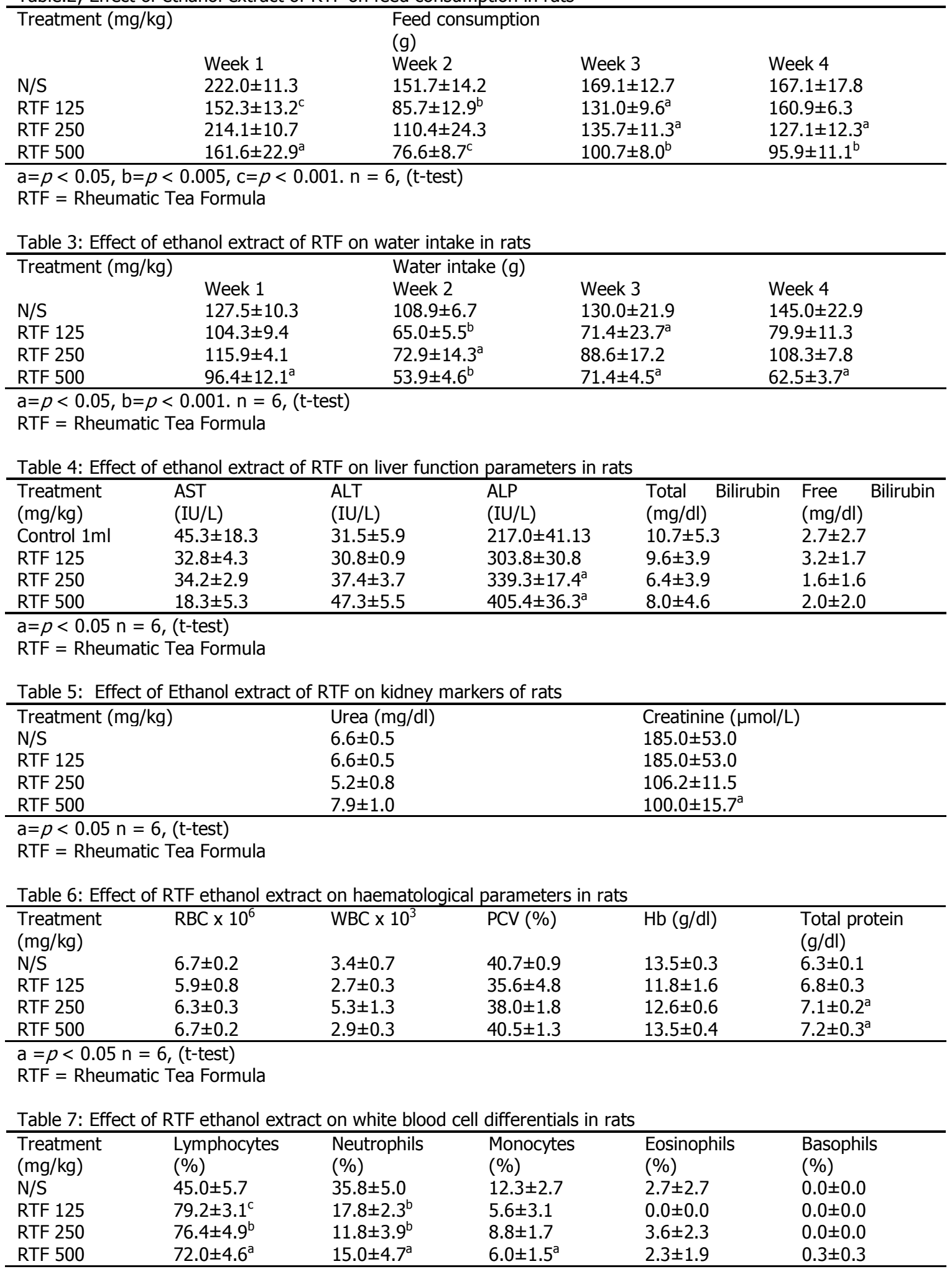

$\mathrm{a}=p \leq 0.05, \mathrm{~b}=p \leq 0.005, \mathrm{c}=p \leq 0.001 . \mathrm{n}=6$, (t-test).

RTF $=$ Rheumatic Tea Formula 
BAJOPAS Volume 9 Number 2 December, 2016

Table 8: Effect of ethanol extract of RTF on the morphology of selected tissues

\begin{tabular}{|c|c|c|c|c|}
\hline Tissue & Control & $125 \mathrm{mg} / \mathrm{kg}$ & $250 \mathrm{mg} / \mathrm{kg}$ & $500 \mathrm{mg} / \mathrm{kg}$ \\
\hline Liver & Unremarkable & Slight necrosis & $\begin{array}{l}\text { Slight necrosis with kupfer } \\
\text { cells hyperplasia }\end{array}$ & Moderate necrosis \\
\hline Kidney & Unremarkable & $\begin{array}{l}\text { Intense tubular and } \\
\text { glomerular necrosis with } \\
\text { lymphocytes hyperplasia }\end{array}$ & $\begin{array}{l}\text { Vacoulation and tubular } \\
\text { necrosis }\end{array}$ & $\begin{array}{l}\text { Moderate tubular and } \\
\text { glomerular necrosis }\end{array}$ \\
\hline Spleen & Unremarkable & $\begin{array}{l}\text { Intense lymphocytes } \\
\text { hyperplasia with normal } \\
\text { red pulp pigments }\end{array}$ & $\begin{array}{l}\text { Intense lymphocytes } \\
\text { hyperplasia with normal red } \\
\text { pulp pigments }\end{array}$ & $\begin{array}{l}\text { Intense lymphocytes } \\
\text { hyperplasia with normal } \\
\text { red pulp pigments }\end{array}$ \\
\hline Stomach & Unremarkable & Unremarkable & $\begin{array}{l}\text { Moderate necrosis with no } \\
\text { ulceration }\end{array}$ & Unremarkable \\
\hline
\end{tabular}

\section{DISCUSSION}

Preliminary phytochemical screening of Rheumatic Tea Formula (RTF) showed the presence of secondary metabolites like glycosides, saponins, alkaloids, reducing sugar and tannins (Aliyu and Samaila, 2015). Also studies on the acute toxicity of RTF revealed $\mathrm{LD}_{50}$ (p.o) value of greater than $5000 \mathrm{mg} / \mathrm{kg}$ which is graded non-toxic but slightly toxic intraperitoneally $(3,808 \mathrm{mg} / \mathrm{kg})$ in rats (Aliyu and Samaila, 2015). Subacute toxicity studies of the extract on body weight, feed consumption, water intake, liver function, kidney profile, haematological indices and histology of some vital organs were evaluated. The extract caused significant $(p<0.05)$ decrease in weight gain of rats which might be due to side effect of the extract, as studies have shown that dietary saponin depresses growth, feed consumption and egg production in poultry (Jenkins and Atwal, 1994). Other reports have ascribed such effects of saponins on reduced feed intake, to the astringent and irritating taste of saponins (Olezek et al., 1994), reduction in intestinal motility (Klita et al., 1996) and a reduction in protein digestion (Shimoyamada et al., 1998). Therefore presence of saponins in the extract might be responsible for decrease in weight as a result of depressed feed consumption as observed with the extract and reduction in protein digestion. The significant $(p<0.05)$ reduction of water intake might also be related to decrease in weight and feed consumption.

The effect of RTF extract on the liver was assessed through blood enzyme activity of Aspartate aminotransferase (AST), alanine aminotransferase $(A L T)$, alkaline phosphatase (ALP) and bilirubin. Liver cell damage is characterized by a rise in plasma enzymes (Clementine and Tar, 2010). The most commonly used indicators of liver damage are the alanine aminotransferase (ALT) and aspartate aminotransferase (AST). These are enzymes normally found in liver cells that leak out of these cells and make their way to the blood when liver cells are injured. ALP is an enzyme in the cells lining of the biliary duct of the liver, osteoblasts of bone, cells of the hepatobiliary tract, intestinal wall, renal tubules and placenta (Hashemi et al., 2008). A rise in plasma alkaline phosphatase (ALP) level is usually a characteristic finding in cholestatic liver disease (Builders et al., 2012).

The significant increase in ALP levels by the ethanol extract of RTF shows that possible cholestasis occurred at the dose levels tested (Orisakwe et al., 2003). This indicates slight adverse effect on the liver since AST, ALT and bilurubin levels were not significantly elevated against the control.

Evaluation of kidney markers showed no significant change in the level of blood urea; however there was a significant $(p<0.05)$ decrease in creatinine blood level. Decrease in blood level of creatinine may not be of clinical significance; in fact it indicates a decrease in muscles mass as observed by decrease in weight gain (William, 2012).

The extract had no effect on blood parameters analysed but caused significant $(p<0.05)$ increase in total blood protein. Increase in total protein may result from burns, liver disease; dehydration etc. (William, 2012).The significant $(p<0.05)$ elevation in lymphocytes may be due to the extract potential to affect lymphocytes while decrease in neutrophils and monocytes may be as a result of effect on bone marrow. Histological investigations on effect of RTF extract were conducted on the liver, kidney, spleen and the stomach. On liver histology, there was slight hepatocellular necrosis with kupfer cells hyperplasia at doses 125 and $250 \mathrm{mg} / \mathrm{kg}$ which signifies a kind of healing process; however $500 \mathrm{mg} / \mathrm{kg}$ dose showed moderate necrosis. This is in conformity with serological analysis earlier observed on the liver suggesting that the extract might be slightly hepatotoxic. Histological investigation on the kidney tissue showed intense tubular and glomerular necrosis at doses of 125 and $250 \mathrm{mg} / \mathrm{kg}$ with the dose of 250 $\mathrm{mg} / \mathrm{kg}$ showing vacoulations of the tubules, however, vacoulations may be a transient physiological response due to the extract which may be reserved by renal regeneration. Necrosis of the tubules and glomerulus was also observed at dose $500 \mathrm{mg} / \mathrm{kg}$. However serological test showed normal blood urea and decreased levels of creatinine which suggests normal kidney functions. The spleen showed intense lymphocytes hyperplasia with necrosis of red pulps and pigments at all doses tested; the intense red pulp necrosis signifies normal destruction of red blood cells either from the effect of the extract or due to aging while lymphocytes hyperplasia signifies normal proliferation of matured lymphocytes. The extract therefore, may not have caused serious deleterious effect on the spleen. The stomach showed normal stomach epithelium at doses 125 and $500 \mathrm{mg} / \mathrm{kg}$; however there was slight necrosis of epithelium at dose of $250 \mathrm{mg} / \mathrm{kg}$ with no ulceration. This result suggests that RTF is devoid of ulcerative tendencies observed with many Non-steroidal Anti-inflammatory Drugs (NSAIDs) and may therefore be safe on the stomach. 


\section{CONCLUSION}

The findings suggest that sub- acute oral administration of ethanol extract of RTF is relatively less toxic except for its effect on the liver and as such should be used with caution at higher doses for treatment of pain and inflammation associated with rheumatism.

\section{RECOMMENDATION}

Further chronic toxicity and Teratogenic studies are suggested before the formula could be recommended for chronic administration.

\section{REFERENCES}

Aliyu, M. and Samaila S.C (2015). Analgesic and Antiinflammatory Activities of Ethanolic Extract of Rheumatic Tea Formula (RTF) in Rats and Mice. International Journal of Herbs and Pharmacological Research. 4 (2): 17-24.

Arsad, S.S, Esa, N.M, Hamzah, H. and Othman F, (2013). Evaluation of acute, sub- acute and sub-chronic oral toxicity of Rhaphidophora decursiva (Roxb), Schott extract in male Sprague Dawley rats. Journal of Medicinal Pant Research: 7(41), pp.3030-3040. Available at: http://www.academicjournals.org/article/arti cle1383308543 Arsad et al.pdf

Builders MI, Isichie CO and Aguiyi,JC (2012). Toxicity Studies of the Extracts of Parkia biglobosa stem bark in rats. British Journal of.Pharmaceutical Research. 2(1):1-16

Chan, I., (1995). Progress in traditional Chinese medicine, Trends Pharm Sci. 16:182-7

Clementine YFY and Tar CA (2010). Liver Function Tests (LFTs) Proceedings of Singapore Healthcare 19 (1):80-82.

Eldin S and Dunford A., (1999). Herbal Medicine in Primary Care, Butterworth-Heinemann, Oxford, UK. Hashemi SR, Zulkifli I, Hair-Bejo M, Farida A and Somchit MN (2008) Acute toxicity study and phytochemical screening of selected herbal aqueous extract in broiler chickens. International Journal of Pharmacology., 4: 352-360.

Ifeoma, O. and Oluwakanyinsola, S., (2013). Screening of Herbal Medicines for Potential Toxicities: Chp.4 pg. 1. Available at: http://dx.doi.org/10.5772/54493.

Jenkins, K. J. and Atwal A. S.,(1994). Effects of dietary saponin on faecal bile acids and

\section{CONTRIBUTION OF AUTHORS}

Author A.M designed the study, wrote the protocol, performed part of the experiments and did all corrections mentioned by the reviewers. Author S.S.C performed the experiments, managed the literature searches, wrote the first draft of the manuscript CONFLICT OF INTEREST- The authors declare no conflict of interest.

neutral sterols and availability of vitamins $A$ and $E$ in Chicks; $J$ Nutri Biochem 5: 134138.

Klita, P.T. Mathison, G.W. and Fenton, T.W., (1996). Effect of alfalfa root saponins on digestive function in sheep; Journal of Animal Science. 74: $1144-1156$

King, E.J. and Armstrong, A.R., (1954). A convenient method of determining serum and bile phosphate activity: Canadian Medical Association Journal, 31:376.

Ogbonnia S.O, Mbaka G.O, Anyika E.N., Emordi J. E. and Nwakakwa N., (2011). An evaluation of acute and sub-chronic toxicities of a Nigerian polyherbal tea remedy: Pakistani Journal of Nutrition, 10:1022-8

Olezek, W., Nowacka, J., Gee, J.M., Wortley, G and Johnson I. T. (1994). Effects of soybean saponins on chymotryptic hydrolyse of soybean proteins. J Agri Food Chem. 46: 4793- 4797

Orisakwe OR, Afonne OJ, Chude MA, Obi E, Dioka CE (2003). Subchronic toxicity studies of the aqueous extract of Boerhavia diffusa leaves. J. Health. Sc., 49, 444-447.

Shimoyamada, M., Ikedo, S., Ootsubo, R. and Watanabe, K. (1998). Effects of soybean saponins on chymotriptic hydrolyse of soybean proteins. Journal of Agricultural Food Chemistry. 46: 4793 - 4797

Sofowora E. A., (1989). Medicinal Plants and Traditional Medicines in Africa; Spectrum Books TietzN.W (Ed) (1985). Fundamentals of Clinical Chemistry. W. B. Sanders, East Bonne.

William M, (2012). Creatinine (serum, plasma), Association of Clinical Biochemistry; pp.1-5 